\title{
ALDH1 expression and potential clinical implications in chronic inflammatory periapical lesions
}

Zilda Betânia Barbosa Medeiros de FARIAS(a)

Leorik Pereira da SILVA ${ }^{(b)}$

José Alcides Almeida DE ARRUDA ${ }^{(c)}$

Jade de Souza CAVALCANTE(a) (D)

Híttalo Carlos Rodrigues de ALMEIDA ${ }^{(a)}$ (i)

Maria Cristina Valença de OLIVEIRA ${ }^{(a)}$

Lélia Batista de SOUZA(d)

Ana Paula Veras SOBRAL(a)

(a) Universidade de Pernambuco - UPE, School of Dentistry, Department of Oral and Maxillofacial Pathology and Oral Medicine, Recife, PE, Brazil.

(b) Universidade Federal do Amazonas - UFAM, Institute of Health and

Biotechnology, Coari, AM, Brazil.

(c) Universidade Federal de Minas Gerais UFMG, School of Dentistry, Department of Oral Surgery and Pathology, Belo Horizonte, MG, Brazil.

(d) Universidade Federal do Rio Grande do Norte - UFRN, Department of Dentistry, Postgraduate Program in Odontology Sciences, Natal, RN, Brazil.

Declaration of Interests: The authors certify that they have no commercial or associative interest that represents a conflict of interest in connection with the manuscript.

\section{Corresponding Author:}

José Alcides Almeida de Arruda

E-mail: alcides_almeida@hotmail.com

ht1ps://doi.org/10.1590/1807-3107bor-2022.vol36.0019

Submitted: December 14, 2020

Accepted for publication: July 5, 2021

Last revision: November 9, 2021
Abstract: Aldehyde dehydrogenase 1 (ALDH-1) is a marker of stem cells in a variety of diseases, but its role in individuals with chronic inflammatory periapical lesions remains unknown. The aim of this study was to investigate the presence of cells with a stem cell profile based on the immunoexpression of ALDH-1 in periapical granulomas (PGs) and radicular cysts (RCs). A total of 51 cases of periapical lesions (25 PGs and 26 RCs) were subjected to immunohistochemical study. The anti-ALDH-1 antibody was applied using the immunoperoxidase technique. An immunoexpression score (intensity vs. percentage of cells) was used, with the cases being classified as low expression (score: 0 to 4 ) and high expression (score: 6 to 9). The Chi-square test was used with a $5 \%$ level of significance. Immunoexpression of ALDH-1 was detected in all cases of PGs and RCs. In PG cases, the expression was diffuse in connective tissue cells, with most cases exhibiting high expression ( $\mathrm{n}=18 ; 69.2 \%$ ), while in $\mathrm{RC}$ cases the expression revealed focal distribution in cells of the capsule and epithelial cells of the cystic lining, with most cases classified as low expression ( $\mathrm{n}=18$; $72 \%)$. Significant differences in the expression scores of ALDH-1 were observed in PGs $(p=0.003)$. The variable expression of ALDH-1 suggests the presence of cells with stem cell profiles in PGs and RCs. These findings suggest that periapical tissues infiltrated by chronic inflammation can recruit important cells for the repair or evolution of periapical lesions.

Keywords: Aldehyde Dehydrogenase 1 Family; Immunohistochemistry; Periapical Diseases; Periapical Granuloma; Radicular Cyst.

\section{Introduction}

Chronic inflammatory periapical lesions, also known as chronic apical periodontitis or periapicopathies, are reactive inflammatory diseases due to the chronic evolution of the process of invasion of the root canal system by microorganisms after pulp tissue necrosis. ${ }^{1,2}$ Worldwide, about $52 \%$ of all adults have at least one tooth with apical periodontitis. ${ }^{3}$ Periapical granulomas (PGs) and radicular cysts (RCs) are the most common conditions among chronic inflammatory periapical lesions. ${ }^{1,2}$ Data from a Brazilian multicenter study on chronic inflammatory periapical 
diseases revealed that RCs and PGs accounted for $59.9 \%$ and $39.6 \%$ of the entire sample, respectively. ${ }^{4}$

In view of the complexity of periodontal tissue and the local inflammatory microenvironment that involve great challenges for tissue repair, the use of stem cells has been recently considered an encouraging strategy for the treatment of tissue damage and inflammation. ${ }^{5}$ Stem cells have remarkable properties, including stemness, proliferation, migration, multiline differentiation, and immunomodulation..$^{5-7}$ The presence of stem cells has already been detected in the periodontal ligament and dental pulp with an inflammatory process, including irreversible pulpitis, and these cells are considered to be similar to stem cells from healthy tissues. ${ }^{6,7}$ Moreover, the presence of stem cells derived from inflamed periapical tissues that demonstrated the immunophenotype of mesenchymal stem cells has been reported, with expression of several surface markers such as STRO-1, CD13, CD29, CD34, CD44, CD45, CD73, CD90, CD105, and CD146. ${ }^{7-9}$ Although studies have indicated that stem cells may be delivered to infectious sites and function as critical players in controlling inflammation and regulating immune responses to achieve regeneration in periodontitis models, the immunomodulatory capabilities of these cells in chronic inflammatory periapical lesions have not been fully elucidated..$^{10,11}$

Aldehyde dehydrogenase (ALDH) is a superfamily of enzymes that detoxify a variety of endogenous and exogenous aldehydes and are necessary for the biosynthesis of retinoic acid and other molecular regulators of cellular function. ${ }^{12}$ The unbalanced biological activity of ALDHs has been linked to vital physiological and toxicological functions in inflammation, metabolic disorders, and cancers. ${ }^{12,13}$ Previous studies have shown that ALDH-1 has been increasingly used as a promising marker for identifying populations of cells with stem cell and/or progenitor profiles. ${ }^{12,13}$ The expression of this enzyme indicates activation of cellular functions related to self-renewal, expansion, and differentiation in both normal and tumor-initiating stem cells. ${ }^{12}$

Considering that ALDH-1 was expressed in dental pulp stem cells, ${ }^{14}$ the identification of cells with potential for division and capacity for selfprogramming into different cell subtypes may be related to the formation, maintenance, and repair of chronic inflammatory periapical lesions. As far as we know, there are no studies available on the expression of ALDH-1 in these lesions. In the present study, we analyzed the immunoexpression of ALDH-1 in order to identify cells with stem cell profiles involved in periapical inflammatory lesions (PGs and RCs) and their possible implications in the inflammation/ repair process.

\section{Methodology}

\section{Ethical approval, study design, and tissue samples}

The study was approved by the Ethics Committee of the University of Pernambuco (Approval No. 10723019.0.1001.514). The patients' identity remained anonymous according to the Declaration of Helsinki.

In a retrospective analysis, the sample was obtained from the archives of a diagnostic center in oral and maxillofacial pathology, University of Pernambuco, Camaragibe, Brazil. A total of 25 cases of PGs and 26 cases of RCs comprised the sample. Clinicopathological information was obtained from the patients' medical records and biopsies regarding sex, age, anatomical location, symptomatology, lesion size, and presence/ absence of endodontic treatment of the tooth related to PG and RC.

All of the patients were treated surgically. The histopathological diagnosis of chronic inflammatory periapical lesions considered classical morphological patterns. The PG was characterized by the presence of granulation tissue with an intense mixed inflammatory infiltrate surrounded by a fibrous connective tissue wall. The RC was characterized by revealing a stratified squamous epithelium, which may demonstrate exocytosis, spongiosis, or hyperplasia. The cystic lumen may be filled with fluid and cellular debris and the cyst wall (capsule) consists of dense fibrous connective tissue that exhibits varying amounts of a chronic inflammatory infiltrate.

\section{Immunohistochemical methods}

For the immunohistochemical study, 3- $\mu$ m-thick sections were obtained from paraffin-embedded tissue blocks and placed on silanized glass slides. The 
cuts were subjected to dewaxing, rehydration, and antigen recovery by immersion in Trilogy solution (Cell Marque; Rocklin, USA) (1:1000 dilution) in an electric pressure cooker. The blocking of endogenous peroxidase was performed with hydrogen peroxide. The primary anti-ALDH-1 antibody (Monoclonal, Abcam; Cambridge, MA, USA) was incubated at 1:2000 dilution in a humid chamber for 60 minutes.

Next, the amplification reaction was performed using the HiDef detection ${ }^{\mathrm{TM}}$ - HRP Polymer System (Cell Marque; Rocklin, CA, USA). The chromogenic agent was diaminobenzidine (DAB; Sigma Chemical, St. Louis, USA) and counterstaining was performed with Harris hematoxylin. Negative controls were obtained by replacing the primary antibodies with normal rabbit serum (Dako; Carpinteria, USA). Samples of human liver were used as positive control, as recommended by the manufacturer.

\section{Immunohistochemical analysis}

Immunohistochemical analysis was performed using a Nikon E200 light microscope (Nikon, Tokyo, Japan). Tissue sections were examined at $\times 100$ and $\times 400$ magnification to identify areas that showed immunoreactive cells. All microscopic fields were examined. The analysis of ALDH-1 protein expression was adapted from the methodology described by Dai et al. ${ }^{15}$ and Huang et al. ${ }^{16}$. The evaluation system considered the percentage and intensity of staining of the cells examined. The percentage was classified as: $0(<5 \%$, negative expression); 1 ( $5-25 \%$, sporadic expression); 2 (> 25\% to < 50\%, focal expression); and 3 (> 50\%, diffuse expression). The intensity of immunostaining was classified as: 0 (negative); 1 (weak); 2 (moderate); and 3 (strong). A final score was determined using the formula: immunoexpression score $=$ intensity $\times$ percentage of cells. Therefore, we obtained the following classification: low expression (score: 0 to 4 ) and high expression (score: 5 to 9).

\section{Data analysis}

Descriptive and quantitative data analysis was conducted using the Statistical Package for the Social Sciences (SPSS) software, version 25.0 (SPSS Inc., Armonk, USA). Qualitative variables were presented in the form of absolute and relative frequencies.
The Pearson Chi-square test was used to assess the association between categorical variables. For all analyses, the level of significance was set at $<0.05$.

\section{Results}

Most of the 51 selected cases were females ( $n=33$; $64.7 \%$ ). Patient age ranged from 13 to 78 years, with a mean of $35.63 \pm 15.6$ years. PG lesions ranged in size from 0.4 to $2 \mathrm{~cm}$, with a mean of $0.9 \pm 0.5 \mathrm{~cm}$, while $\mathrm{RC}$ lesions ranged from 0.3 to $3 \mathrm{~cm}$, with a mean of $1.6 \pm 0.8 \mathrm{~cm}$. The lesions were located mainly in the maxilla (26 in the anterior region and nine in the posterior region). With respect to symptomatology, 21 cases were symptomatic (i.e., presence of pain, flushing, and/or pressure). Most of the lesions did not have previous endodontic treatment (78.4\%) (Table 1).

Regarding the immunohistochemical expression of ALDH-1 in the studied chronic inflammatory periapical lesions, all cases exhibited positivity for this enzyme. In PGs, the expression of ALDH-1 was diffuse in cells of mesenchymal morphology in the capsule and central region of the lesions. When the final categorized score was assessed, it was observed that most PG cases were classified with a high expression score $(n=18 ; 72.0 \%)$. In RC cases, the presence of sporadic immunopositive cells with focal distribution (cystic epithelium and cells with mesenchymal morphology in the capsule) was observed. Most RC cases were classified as having low expression scores $(n=18 ; 69.2 \%)$. Figures $1 \mathrm{~B}$ and 1D illustrate the expression of ALDH-1 in both conditions.

ALDH1 immunoexpression was different between PGs and RCs ( $p=0.003)$ but it showed no statistical association and/or difference with the clinicopathological variables of the study. There were no significant differences between the expression of ALDH-1 and the other clinical variables analyzed. Despite the absence of a statistically significant association, it was observed that cases of chronic inflammatory periapical lesions with endodontically treated teeth showed greater expression of ALDH-1 (Table 2). However, when the chronic inflammatory periapical lesions were evaluated separately (i.e., PGs or RCs), there were also no statistically significant 
Table 1. Clinicopathologic data of individuals with periapical granulomas and radicular cysts.

\begin{tabular}{|c|c|c|c|}
\hline Variables & Periapical granuloma $(n=25)$ & Radicular cyst ( $n=26$ ) & Total $(n=51)$ \\
\hline \multicolumn{4}{|l|}{ Sex } \\
\hline Female & 17 & 16 & $33(64.7 \%)$ \\
\hline Male & 8 & 10 & $18(35.3 \%)$ \\
\hline \multicolumn{4}{|l|}{ Age } \\
\hline$\leq 40$ & 12 & 18 & $30(58.8 \%)$ \\
\hline$>40$ & 13 & 8 & $21(41.2 \%)$ \\
\hline \multicolumn{4}{|c|}{ Anatomical location } \\
\hline Maxilla & 17 & 18 & $35(68.6 \%)$ \\
\hline Mandible & 8 & 8 & $16(31.4 \%)$ \\
\hline \multicolumn{4}{|l|}{ Symptomatology } \\
\hline Asymptomatic & 17 & 13 & $30(58.8 \%)$ \\
\hline Symptomatic & 8 & 13 & $21(41.2 \%)$ \\
\hline \multicolumn{4}{|l|}{ Size } \\
\hline$\leq 1 \mathrm{~cm}$ & 18 & 9 & $27(52.9 \%)$ \\
\hline$>1 \mathrm{~cm}$ & 7 & 17 & $24(47.1 \%)$ \\
\hline \multicolumn{4}{|c|}{ Endodontic treatment } \\
\hline Not treated & 17 & 23 & $40(78.4 \%)$ \\
\hline Treated & 8 & 3 & $11(21.6 \%)$ \\
\hline
\end{tabular}

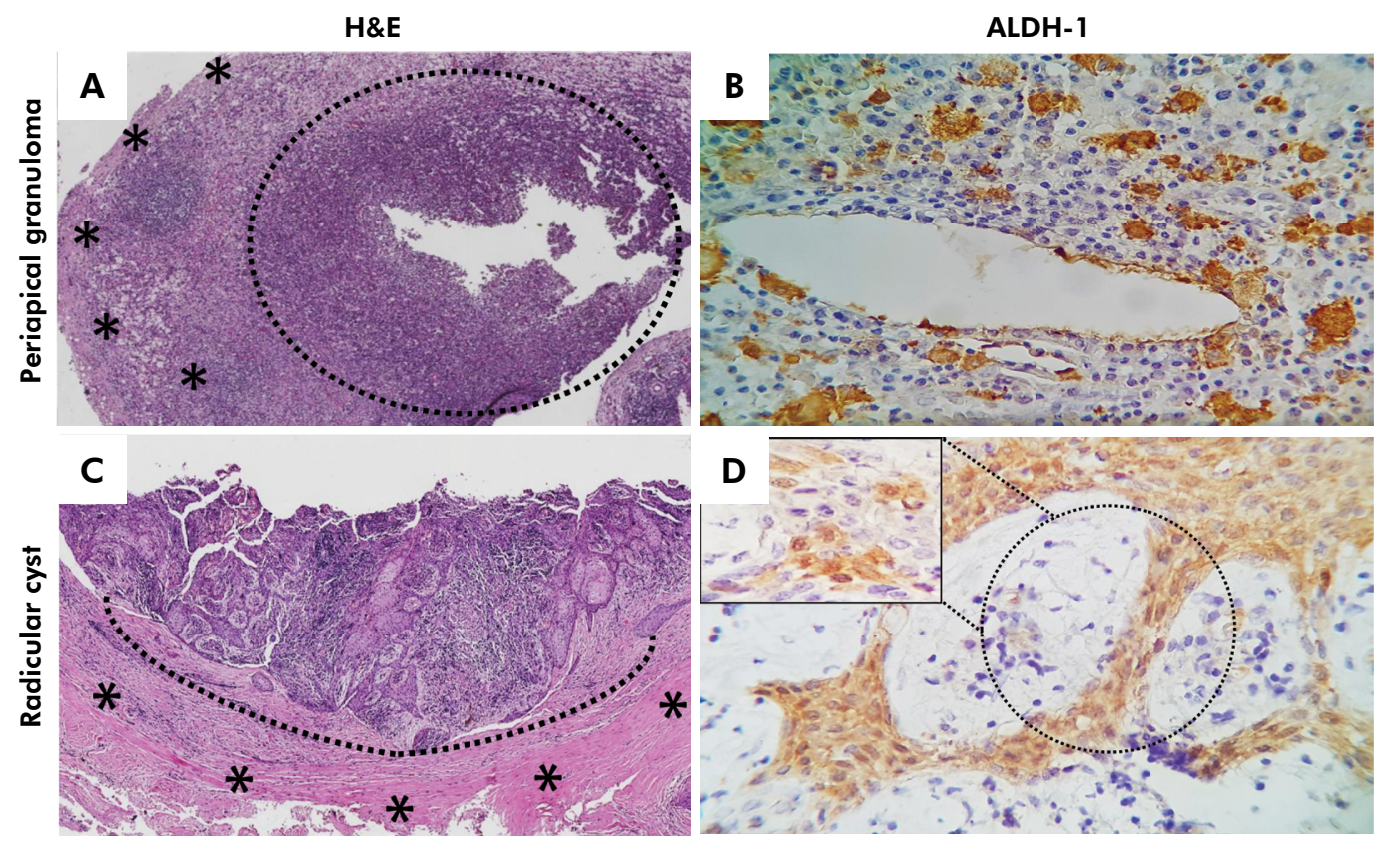

Figure 1. Photomicrograph of a periapical granuloma and radicular cyst. (A) Granuloma capsule (asterisks) and central region of the lesion (dashed circle). (C) Periapical cyst exhibiting a cystic capsule (asterisks) and arciform epithelial lining (above the dashed line). Cytoplasmic immunoexpression of $\mathrm{ALDH}-1$ in the periapical granuloma and radicular cyst. (B) Diffuse cytoplasmic immunostaining in cells of the center of a periapical granuloma. (D) Diffuse immunostaining of epithelial cells of the periapical cyst $(A, C: H \& E, \times 20 ; B, D: I H C, \times 40)$. 
Table 2. Association of ALDH-1 protein expression and clinicopathological data of cases of periapical granulomas and radicular cysts.

\begin{tabular}{|c|c|c|c|}
\hline \multirow{2}{*}{ Variables } & \multicolumn{2}{|c|}{ ALDH-1 expression } & \multirow{2}{*}{$\mathrm{p}$-value } \\
\hline & Low expression n (\%) & High expression n (\%) & \\
\hline \multicolumn{4}{|l|}{ Lesion } \\
\hline Radicular cyst & $18(72.0)$ & $8(30.8)$ & \multirow{2}{*}{0.003} \\
\hline Periapical granuloma & $7(28.0)$ & $18(69.2)$ & \\
\hline \multicolumn{4}{|l|}{ Sex } \\
\hline Female & $13(52.0)$ & $20(76.9)$ & \multirow{2}{*}{0.063} \\
\hline Male & $12(48.0)$ & $6(23.1)$ & \\
\hline \multicolumn{4}{|l|}{ Age } \\
\hline$\leq 40$ & $15(60.0)$ & $15(57.7)$ & \multirow{2}{*}{0.867} \\
\hline$>40$ & $10(40.0)$ & 11 (42.3) & \\
\hline \multicolumn{4}{|l|}{ Anatomical location } \\
\hline Maxilla & $17(68.0)$ & $18(69.2)$ & \multirow{2}{*}{0.920} \\
\hline Mandible & $8(32.0)$ & $8(30.8)$ & \\
\hline \multicolumn{4}{|l|}{ Symptomatology } \\
\hline Asymptomatic & $13(52.0)$ & $17(65.4)$ & \multirow{2}{*}{0.332} \\
\hline Symptomatic & $12(48.0)$ & $9(34.6)$ & \\
\hline \multicolumn{4}{|l|}{ Size } \\
\hline$\leq 1 \mathrm{~cm}$ & $12(48.0)$ & $15(57.7)$ & \multirow{2}{*}{0.488} \\
\hline$>1 \mathrm{~cm}$ & $13(52.0)$ & $11(42.3)$ & \\
\hline \multicolumn{4}{|l|}{ Endodontic treatment } \\
\hline Not treated & $22(88.0)$ & $18(69.2)$ & \multirow{2}{*}{0.103} \\
\hline Treated & $3(12.0)$ & 8 (30.8) & \\
\hline
\end{tabular}

"Chi-square test.

differences between the expression of ALDH-1 and clinicopathological variables (Tables 3 and 4).

PG cases showed more immunopositive cells both in the connective tissue capsule and in the central region of the lesions; however, RC cases also had fewer positive cells in the connective tissue capsule. The immunopositive cells in the capsule showed mesenchymal morphology (oval and spindle shaped) in both lesions. Additionally, the presence of odontogenic epithelium remnants (Malassez epithelial remnants) was observed inside the connective tissue/capsule that exhibited ALDH-1 expression, both in cases of RCs ( $n=16 ; 65.4 \%$ ) and PGs ( $\mathrm{n}=12 ; 48.0 \%$ ) (Figure 2B and 2D).

\section{Discussion}

A high activity of ALDH-1 has been shown to be a property of a subset of human hematopoietic cells, but the regulation and the role of ALDH-1 in chronic inflammatory periapical lesions is virtually

Table 3. Analysis of ALDH- 1 expression in periapical granulomas.

\begin{tabular}{|c|c|c|c|}
\hline \multirow[b]{2}{*}{ Variables } & \multicolumn{2}{|c|}{ ALDH-1 expression } & \multirow[b]{2}{*}{$p$-value } \\
\hline & $\begin{array}{c}\text { Low expression } \\
\mathrm{n}(\%)\end{array}$ & $\begin{array}{c}\text { High expression } \\
\mathrm{n}(\%)\end{array}$ & \\
\hline \multicolumn{4}{|l|}{ Sex } \\
\hline Female & $3(42.8)$ & $14(77.8)$ & \multirow{2}{*}{$0.156^{*}$} \\
\hline Male & $4(57.2)$ & $4(22.2)$ & \\
\hline \multicolumn{4}{|l|}{ Age } \\
\hline$\leq 40$ & $5(71.4)$ & $12(66.7)$ & \multirow{2}{*}{$1.000^{*}$} \\
\hline$>40$ & $2(28.6)$ & $6(33.4)$ & \\
\hline \multicolumn{4}{|c|}{ Anatomical location } \\
\hline Maxilla & $5(71.4)$ & $12(66.7)$ & \multirow{2}{*}{$1.000^{*}$} \\
\hline Mandible & $2(28.6)$ & $6(33.4)$ & \\
\hline \multicolumn{4}{|l|}{ Symptomatology } \\
\hline Asymptomatic & $3(42.8)$ & $14(77.8)$ & \multirow{2}{*}{$0.156^{*}$} \\
\hline Symptomatic & $4(57.2)$ & $4(22.2)$ & \\
\hline \multicolumn{4}{|l|}{ Size } \\
\hline$\leq 1 \mathrm{~cm}$ & $5(71.4)$ & $13(72.2)$ & \multirow{2}{*}{$1.000^{*}$} \\
\hline$>1 \mathrm{~cm}$ & $2(28.6)$ & $5(27.8)$ & \\
\hline \multicolumn{4}{|c|}{ Endodontic treatment } \\
\hline Not treated & $6(85.7)$ & $11(61.1)$ & \multirow{2}{*}{$0.362^{*}$} \\
\hline Treated & 1 (14.3) & 7 (38.9) & \\
\hline
\end{tabular}


Table 4. Analysis of ALDH-1 expression in radicular cysts.

\begin{tabular}{|c|c|c|c|}
\hline \multirow{2}{*}{ Variables } & \multicolumn{2}{|c|}{ ALDH-1 expression } & \multirow{2}{*}{$\mathrm{p}$-value } \\
\hline & Low expression n (\%) & High expression $n(\%)$ & \\
\hline \multicolumn{4}{|l|}{ Sex } \\
\hline Female & $10(55.5)$ & $6(75.0)$ & \multirow{2}{*}{$0.420^{\circ}$} \\
\hline Male & $8(44.5)$ & $2(25.0)$ & \\
\hline \multicolumn{4}{|l|}{ Age } \\
\hline$\leq 40$ & $12(66.7)$ & $6(75.0)$ & \multirow{2}{*}{1.000} \\
\hline$>40$ & $6(33.3)$ & $2(25.0)$ & \\
\hline \multicolumn{4}{|c|}{ Anatomical location } \\
\hline Maxilla & $12(66.7)$ & $6(75.0)$ & \multirow{2}{*}{1.000} \\
\hline Mandible & $6(33.3)$ & $2(25.0)$ & \\
\hline \multicolumn{4}{|l|}{ Symptomatology } \\
\hline Asymptomatic & $10(55.5)$ & $3(37.5)$ & \multirow{2}{*}{$0.673^{*}$} \\
\hline Symptomatic & $8(45.5)$ & $5(62.5)$ & \\
\hline \multicolumn{4}{|l|}{ Size } \\
\hline$\leq 1 \mathrm{~cm}$ & 7 (38.9) & $2(25.0)$ & \multirow{2}{*}{$0.667^{*}$} \\
\hline$>1 \mathrm{~cm}$ & $11(61.1)$ & $6(75.0)$ & \\
\hline \multicolumn{4}{|c|}{ Endodontic treatment } \\
\hline Not treated & $16(88.9)$ & 7 (87.5) & \multirow{2}{*}{1.000} \\
\hline Treated & $2(11.1)$ & 1 (12.5) & \\
\hline
\end{tabular}

*Fisher's exact test.
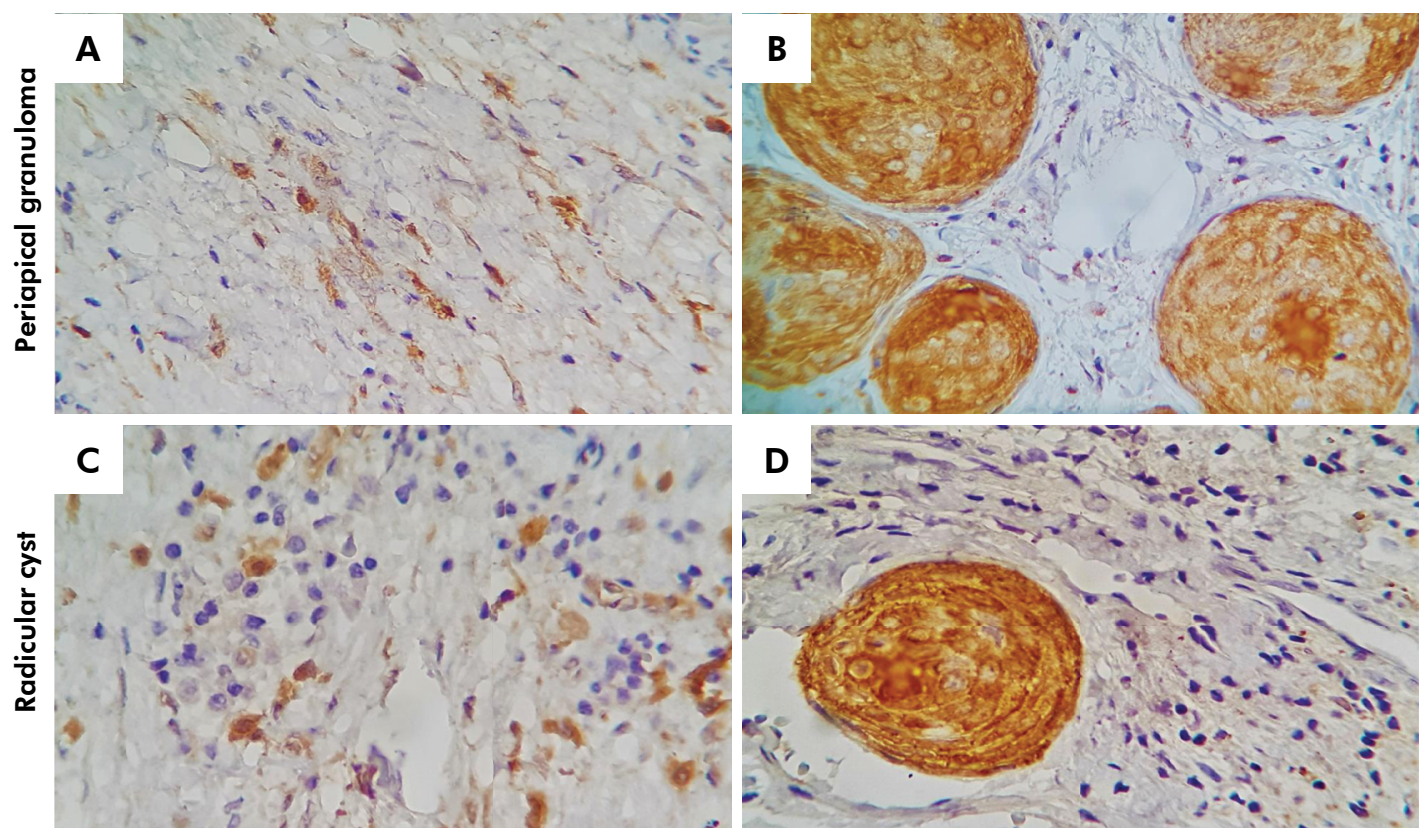

Figure 2. Photomicrographs of ALDH-1 immunoexpression in mesenchymal cells present in lesion capsules. (A) Periapical granuloma capsule. (C) Radicular cyst capsule. (B, D) Presence of odontogenic epithelium remains inside the capsule showing ALDH-1 immunoexpression, both in the periapical granuloma and radicular cyst (A-D: IHC, $\times 40)$. 
unknown. In the present study, we noticed the expression of ALDH-1 in all PG and RC cases, which indicates the presence of cells with a stem cell profile distributed in both conditions. This fact agrees with previous studies that used different markers to identify mesenchymal stem/progenitor cells in periapical inflammatory tissues. ${ }^{8,17,18,19}$ In fact, the expression of stem cells markers in connective tissue cells of chronic inflammatory periapical lesions may be indicative of a phenotype compatible with mesenchymal stem cells. According to Liao et al., ${ }^{8}$ mesenchymal progenitor cells were present in inflamed periapical tissues, as determined by the expression of theSTRO-1 and CD146 markers. Herein, ALDH-1 was also immunoexpressed in cells with mesenchymal morphology and in the capsule of periapical lesions.

Although studies have not yet reached a consensus about a specific molecular signature for the characterization of stem cells, cells with a profile compatible with mesenchymal stem cells are generally identified by means of a set of cell surface markers. ${ }^{5,10,11}$ However, no specific and/or unique ideal marker has been established to characterize the most primitive cells and to clearly identify their different stages or activation. ${ }^{20}$ Some investigations have indicated as an alternative for the characterization of stem cells the use of universal markers, such as some enzymes of the ALDH family, mainly in their isoform $1 .{ }^{13}$ The ALDH-1 enzyme represents an intracellular metabolic marker which has been used mainly in research with breast and salivary gland tumors. ${ }^{12,13,20-25} \mathrm{On}$ the other hand, a study demonstrated that ALDH-1 was expressed by cells isolated from the dental pulp, which had characteristics of mesenchymal stem cells, and suggested that ALDH-1 is a potential marker employed for dental pulp stem cells. ${ }^{14}$

A previous study analyzed the immunoexpression of stem cell markers in persistent periapical lesions (with endodontic treatment) and primary lesions (without endodontic treatment). ${ }^{19}$ There was no difference in SOX2 expression between lesions with or without treatment, and the greatest expression of CD90 occurred in persistent lesions. ${ }^{19}$ In our study, however, 8 of the 11 cases of periapical persistent lesions (with endodontic treatment) showed a high expression of ALDH-1. In this respect, the expression of this protein in the lesions studied herein suggests that cells with a stem cell profile may be related to the process of maintenance of chronic lesions, even with the decrease in the antigenic stimulus by bacterial infections. This greater number of cells with a stem cell profile may also be related to the repair process most evident after treatment. In line with Estrela et al., ${ }^{19}$ stem cells can contribute to the immunosuppressive environment in persistent lesions. In addition, different sources of stem cells may be associated with the chronic nature of primary lesions, as well as the development of persistent lesions. ${ }^{19,26}$

Araujo-Pires et al. ${ }^{17}$ identified the expression of CD29, CD73, CD90, CD146, CD166, NANOG, Stro-1, and CXCR4 in human periapical lesions and experimental periapical lesions produced in mice. Interestingly, immunoexpression was more prevalent in PGs and in inactive lesions, similar to the findings of the present study. Accordingly, the greatest expression in inactive lesions found by the cited study ${ }^{17}$ may be related to the recruitment of stem cells in perivascular niches and in the periodontal ligament to the microenvironment of the periapical lesion through cell mobilization, proliferation, and/or differentiation, resulting in partial repair of inactive lesions. ${ }^{27}$

Stem cells are activated or emerge in the periapical region in the presence of an inflammatory stimulus and, thus, play their immunosuppressive and/or prorepairing role. ${ }^{8,19,28}$ Considering the origin of these stem cells from periapical lesions, they can also be actively recruited from the perivascular region and/or periodontal ligament to the lesion microenvironment, certainly due to the action of the stem cell factor, an important stem cell activating cytokine that acts on the proliferation, migration, survival, and differentiation of hematopoietic progenitor cells, melanocytes, and germ cells. ${ }^{29}$ Nevertheless, in view of a greater expression of labeled cells in PGs and in agreement with a previous study, ${ }^{17}$ we may infer that these conditions are capable of presenting greater capacity for differentiation and/or proliferation of cells with a stem cell profile. Reinforcing the reaction capacity of PGs, some studies have unveiled that granulation tissues in the periapical region contain osteogenic cells $^{27,30}$ and, possibly, these cells in inflamed tissues 
differentiate into osteoblasts and can regenerate periapical bone once the source of infection has been removed. However, further studies including chronic inflammatory periapical lesions in order to identify, isolate, characterize phenotypically, and evaluate their functions with differentiation pathways may be useful for the therapeutic evolution of these conditions, particularly with the proposal to isolate these cells at different stages of the periapical inflammatory/ reactive process.

\section{Conclusion}

In summary, all cases of PGs and RCs were positive for ALDH-1. In particular, most PG cases revealed a high expression score, while RC cases showed the presence of sporadic immunopositive cells with focal distribution. Thus, the presence of cells with a stem cell profile in PGs and RCs may be related to the maintenance and attempted repair of these conditions.

\section{Acknowledgements}

This study was supported by Coordenação de Aperfeiçoamento de Pessoal de Nível Superior (CAPES, Finance Code 001), Brazil. J.A.A.A. is recipient of fellowship. We would like to thank Conselho Nacional de Desenvolvimento Científico e Tecnológico (CNPq), Brazil. Mrs. E. Greene provided English editing of the manuscript.

\section{References}

1. Weber M, Schlittenbaver T, Moebius P, Büttner-Herold M, Ries J, Preidl R, et al. Macrophage polarization differs between apical granulomas, radicular cysts, and dentigerous cysts. Clin Oral Investig. 2018 Jan;22(1):385-94. https://doi.org/10.1007/s00784-017-2123-1

2. Tavares DP, Rodrigues JT, Dos Santos TC, Armada L, Pires FR. Clinical and radiological analysis of a series of periapical cysts and periapical granulomas diagnosed in a Brazilian population. J Clin Exp Dent. 2017 Jan;9(1):e129-35. https://doi.org/10.4317/jced.53196

3. Tibúrcio-Machado CS, Michelon C, Zanatta FB, Gomes MS, Marin JA, Bier CA. The global prevalence of apical periodontitis: a systematic review and meta-analysis. Int Endod J. 2021 May;54(5:712-35. https://doi.org/10.1111/iej.13467

4. Couto AM, Meirelles DP, Valeriano AT, Almeida DS, Moraes Ê, Tarquinio SB, et al. Chronic inflammatory periapical diseases: a Brazilian multicenter study of 10,381 cases and literature review. Braz Oral Res. 2021 Mar;35:e033. https://doi.org/10.1590/1807-3107bor-2021.vol35.0033

5. Wang $M$, Xie J, Wang C, Zhong D, Xie L, Fang H. Immunomodulatory properties of stem cells in periodontitis: current status and future prospective. Stem Cells Int. 2020 Jul;2020:9836518. https://doi.org/10.1155/2020/9836518

6. Alongi DJ, Yamaza T, Song Y, Fouad AF, Romberg EE, Shi S, et al. Stem/progenitor cells from inflamed human dental pulp retain tissue regeneration potential. Regen Med. 2010 Jul;5(4):617-31. https://doi.org/10.2217/rme.10.30

7. Park JC, Kim JM, Jung IH, Kim JC, Choi SH, Cho KS, et al. Isolation and characterization of human periodontal ligament (PDL) stem cells (PDLSCs) from the inflamed PDL tissue: in vitro and in vivo evaluations. J Clin Periodontol. 2011 Aug;38(8):721-31. https://doi.org/10.1111/j.1600-051X.2011.01716.x

8. Liao J, Al Shahrani M, Al-Habib M, Tanaka T, Huang GT. Cells isolated from inflamed periapical tissue express mesenchymal stem cell markers and are highly osteogenic. J Endod. 2011 Sep;37(9):1217-24. https://doi.org/10.1016/i.joen.2011.05.022

9. Marrelli M, Paduano F, Tatullo M. Cells isolated from human periapical cysts express mesenchymal stem cell-like properties. Int J Biol Sci. 2013 Nov;9(10):1070-8. https://doi.org/10.7150/ijbs.6662

10. Kim JH, Jo CH, Kim HR, Hwang YI. Comparison of immunological characteristics of mesenchymal stem cells from the periodontal ligament, umbilical cord, and adipose tissue. Stem Cells Int. 2018 Apr;2018:8429042. https://doi.org/10.1155/2018/8429042

11. Sriram G, Natu VP, Islam I, Fu X, Seneviratne CJ, Tan KS, et al. Innate immune response of human embryonic stem cell-derived fibroblasts and mesenchymal stem cells to periodontopathogens. Stem Cells Int. 2016;2016:8905365. https://doi.org/10.1155/2016/8905365

12. Vassalli G. Aldehyde dehydrogenases: not just markers, but functional regulators of stem cells. Stem Cells Int. 2019 Jan;2019:3904645. https://doi.org/10.1155/2019/3904645

13. Douville J, Beaulieu R, Balicki D. ALDH1 as a functional marker of cancer stem and progenitor cells. Stem Cells Dev. 2009 JanFeb;18(1):17-25. https://doi.org/10.1089/scd.2008.0055 
Farias ZBBM, Silva LP, De Arruda JAA, Cavalcante JS, Almeira HCR, Oliveira MCV, et al.

14. Machado CV, Passos ST, Campos TM, Bernardi L, Vilas-Bôas DS, Nör JE, et al. The dental pulp stem cell niche based on aldehyde dehydrogenase 1 expression. Int Endod J. 2016 Aug;49(8):755-63. https://doi.org/10.1111/iej.12511

15. Dai W, Tan X, Sun C, Zhou Q. High expression of SOX2 is associated with poor prognosis in patients with salivary gland adenoid cystic carcinoma. Int J Mol Sci. 2014 May;15(5):8393-406. https://doi.org/10.3390/ijms15058393

16. Huang YH, Luo MH, Ni YB, Tsang JY, Chan SK, Lui PC, et al. Increased SOX2 expression in less differentiated breast carcinomas and their lymph node metastases. Histopathology. 2014 Mar;64(4):494-503. https://doi.org/10.1111/his.12257

17. Araujo-Pires AC, Biguetti CC, Repeke CE, Rodini CO, Campanelli AP, Trombone AP, et al. Mesenchymal stem cells as active prohealing and immunosuppressive agents in periapical environment: evidence from human and experimental periapical lesions. J Endod. 2014 Oct;40(10):1560-5. https://doi.org/10.1016/i.joen.2014.02.012

18. Dokić J, Tomić S, Cerović S, Todorović V, Rudolf R, Colić M. Characterization and immunosuppressive properties of mesenchymal stem cells from periapical lesions. J Clin Periodontol. 2012 Sep;39(9):807-16. https://doi.org/10.1111/j.1600-051X.2012.01917.x

19. Estrela C, Silva BSF, Silva JA, Yamamoto-Silva FP, Pinto-Júnior DD, Gomez RS. Stem cell marker expression in persistent apical periodontitis. J Endod. 2017 Jan;43(1):63-8. https://doi.org/10.1016/i.joen.2016.09.002

20. Calloni R, Cordero EA, Henriques JA, Bonatto D. Reviewing and updating the major molecular markers for stem cells. Stem Cells Dev. 2013 May;22(9):1455-76. https://doi.org/10.1089/scd.2012.0637

21. Pal D, Kolluru V, Chandrasekaran B, Baby BV, Aman M, Suman S, et al. Targeting aberrant expression of Notch-1 in ALDH+ cancer stem cells in breast cancer. Mol Carcinog. 2017 Mar;56(3):1127-36. https://doi.org/10.1002/mc.22579

22. Lee JS, Kim WG. Potential protective effect of ALDH-1 stromal expression against early recurrence of operable breast cancers. Stem Cell Investig. 2018 Nov; 5:43. https://doi.org/10.21037/sci.2018.11.03

23. Seifi S, Seyedmajidi M, Salehinejad J, Gholinia H, Aliakbarpour F. Immunohistochemical expression of CD56 and ALDH1 in common salivary gland tumors. Iran J Otorhinolaryngol. 2016 Nov;28(89):389-97.

24. Adams A, Warner K, Pearson AT, Zhang Z, Kim HS, Mochizuki D, et al. ALDH/CD44 identifies uniquely tumorigenic cancer stem cells in salivary gland mucoepidermoid carcinomas. Oncotarget. 2015 Sep;6(29):26633-50. https://doi.org/10.18632/oncotarget.5782

25. Silva LP, Lopes ML, Sarmento AS, Borges MA, Moura SR, Sobral AP, et al. Increased expression of ALDH-1 is associated with clinical parameters of salivary glands neoplasms. Exp Mol Pathol. 2020 Dec;117:104552. https://doi.org/10.1016/i.yexmp.2020.104552

26. Shi Y, Su J, Roberts Al, Shou P, Rabson AB, Ren G. How mesenchymal stem cells interact with tissue immune responses. Trends Immunol. 2012 Mar;33(3):136-43. https://doi.org/10.1016/j.it.2011.11.004

27. Garlet GP, Horwat R, Ray HL Jr, Garlet TP, Silveira EM, Campanelli AP, et al. Expression analysis of wound healing genes in human periapical granulomas of progressive and stable nature. J Endod. 2012 Feb;38(2):185-90. https://doi.org/10.1016/i.joen.2011.09.011

28. Patel J, Gudehithlu KP, Dunea G, Arruda JA, Singh AK. Foreign body-induced granulation tissue is a source of adult stem cells. Transl Res. 2010 Apr;155(4):191-9. https://doi.org/10.1016/j.trsl.2009.08.010

29. Lennartsson J, Rönnstrand L. Stem cell factor receptor/c-Kit: from basic science to clinical implications. Physiol Rev. 2012 Oct;92(4):1619-49. https://doi.org/10.1152/physrev.00046.2011

30. Maeda H, Wada N, Nakamuta H, Akamine A. Human periapical granulation tissue contains osteogenic cells. Cell Tissue Res. 2004 Feb;315(2):203-8. https://doi.org/10.1007/s00441-003-0832-z 